\title{
Article
}

\section{Teaching Writing in Vietnam's Secondary and High Schools}

\author{
Vu Phi Ho Pham ${ }^{1, *}$ and Minh Hoa Truong ${ }^{2}$ \\ 1 Faculty of Foreign Languages, Van Lang University, Ho Chi Minh City 700000, Vietnam \\ 2 Faculty of Foreign Languages, HCMC Open University, Ho Chi Minh City 700000, Vietnam; \\ ngut_minh_hoa@yahoo.com.vn \\ * Correspondence: ho.pvp@vlu.edu.vn; Tel.: +84-909850699
}

check for

updates

Citation: Pham, V.P.H.; Truong, M.H Teaching Writing in Vietnam's Secondary and High Schools. Educ. Sci. 2021, 11, 632. https://doi.org/ 10.3390/educsci11100632

Academic Editor: Maureen Kendrick

Received: 7 August 2021

Accepted: 24 September 2021

Published: 12 October 2021

Publisher's Note: MDPI stays neutral with regard to jurisdictional claims in published maps and institutional affiliations.

Copyright: (c) 2021 by the authors. Licensee MDPI, Basel, Switzerland. This article is an open access article distributed under the terms and conditions of the Creative Commons Attribution (CC BY) license (https:// creativecommons.org/licenses/by/ $4.0 /)$.

\begin{abstract}
The current study adopted features of a survey research design to examine the EFL high school teachers' beliefs about writing and its teaching, their actual classroom practices, and the interplays between their beliefs and practices in the realm of EFL writing instruction. A sample of seventy-six EFL teachers from the eight selected high schools situated in Ho Chi Minh City was recruited for the current survey. The beliefs and practices of EFL writing instruction of these studied teachers were elicited through a thirty-nine-item questionnaire, which was qualitatively analyzed by SPSS 20.0. The study results showed that most of the participants held different views/orientations about writing skills and teaching writing, consisting of form-based, cognitive process-based, functional social-based, and interactive social-based views; nevertheless, the formbased orientation was still most dominant in their beliefs. On the contrary, in practice, most high school teachers followed the product approach, which underlies form-based orientation in lieu of different approaches, explicitly interpreting the writing section's low results in the Vietnamese National GCSE examination in recent years.
\end{abstract}

Keywords: teaching writing; teacher's belief; classroom practice; writing skills

\section{Introduction}

Since the academic year of 2013-2014, writing a paragraph to respond to a given topic has been required in the English paper of the Vietnamese National GCSE (General Certificate for Secondary Education) Examination in the Vietnamese context. Ironically, the results of these papers were mainly between 2.0 and 3.5 points. Basically, these unexpected scores stemmed from the fact that a large number of high school candidates did not know how to construct the text or skipped their writing section, which registers at $20 \%$ of the whole English paper. Surprisingly, this problem also recurred in the following academic years. Some students found the writing section truly burdensome. In addition, others admitted that the habit of rote memorizing sample texts supplied by the teachers made it difficult for them to complete the writing task within some small changes in the topic.

As it happens, most high school students did not possess any strategies for composing texts independently but normally practice writing in a tightly controlled way. This is very consistent with what Khanalizadeh and Allami [1] delineated about writing teaching and learning in Iran-“"writing skill is often limited to making sentences, and the grammatical points of those sentences are the most important parts of learning how to write" (p. 334). Originally, Tran [2], Duong [3], and Nguyen [4] described that writing skills had been conducted in the solid Vietnamese classrooms where students are automatically attributed to passive receivers of language knowledge rather than language construction while the teachers tend to be powerful centers. Furthermore, such unsatisfactory outputs of the writing section in the National GCSE examination in consecutive recent years evinced that writing is a difficult, sophisticated, social activity and an important skill for language learners [5-7], necessitating "the mastery of a variety of linguistic, cognitive, and sociocultural competencies" [8], (p. 35). Alternatively saying, being capable of writing well requires 
more than linguistic knowledge and memory of sample texts; it also urges learner writers to know how to construct their texts independently (cognitive view) and active interaction with other writers in the learning process (social view). As a matter of fact, letting high school students imitate and memorize the sample texts might only yield its temporary effect on exam-driven purposes to some extent.

The aforementioned alarming situation has given rise to some doubts such as whether writing skill is "truly perceived" and "equally treated" as other language skills in high school context, and whether teaching activities and teacher roles undertaken in writing classrooms are genuinely advantageous to the development of high school students' writing ability. Thereby, investigating how high school teachers believe in writing instruction and govern writing lessons in practice should be taken into consideration. Literally, understanding these teachers' beliefs and actual classroom practices could partly elucidate such low results of the given writing section in the Vietnamese National GCSE examination in recent successive years. Khalifa, Ahmed and Ismael [9], Nguyen and Newton [10], and Widiastuti et al. [11] also asserted that the teachers' beliefs are not always applied to their practices in the classrooms approximately. Saputra, Suherdi, and Rodliyah [12] found that the teachers' length of teaching experiences and past experiences as a learner was the most factors to affect the way they practiced teaching. However, the teachers' beliefs were not usually implemented in the classrooms. This necessity derives from the fact that "teachers are one of the key factors in delivering instruction that leads to the development of competent literacy learners" [13], (p. 23).

\subsection{Teachers' Beliefs in Writing Instruction}

As teachers play such a critical role in developing learners' writing performance, their beliefs have also become a key issue in education since what they believe and what they do not believe has an imperceptible influence on their classroom behaviors [14]. This may originate from the view posited by Borg [15] that "teachers are active, thinking decision-makers who make instructional choices by drawing on complex practically-oriented, personalized, and context-sensitive networks of knowledge, thoughts, and beliefs" (p. 81). In recapitulation, teacher beliefs are cognitive tools that powerfully shape or control a teacher's behaviors, instructional choices, material development, etc.

Peculiar to the field of writing instruction, in recent years, researchers have shown an increased interest in exploring how teachers think, feel, and perceive about the nature of writing, their teacher roles and teaching in the classroom, as well as the congruence between what they believe and what they actually do in writing instruction [1,9-12,16-24]. Since an exploration of teachers' beliefs is at the heart of our understanding of their planning, instructional decisions, and classroom practices, the researchers decided to seek what beliefs the selected high school teachers in Ho Chi Minh City, Vietnam holds about the nature of writing, as well as about their roles and orientations to teaching writing for the high school level.

\subsection{Beliefs in the Nature of Writing Skill}

In the realm of teaching writing skills, it is of utmost importance to explore teachers' perceptions or views about the nature of writing due to the fact that "teachers can have very limited to very eclectic views of their subject and that in some cases their ideas about subjects vary from one context to another" [25], (p. 35). In other words, according to every particular educational environment in which we work, beliefs about the nature of writing can be different to some extent. For example, there is a belief that the content of writing is single and consistently true in many cases, often imposed by teachers. However, from another belief, the content of writing requires being socially contextual, particular situational, and purposeful. In this case, writing is a social activity to achieve communicative goals. Writing is built on the basis of ranges of vocabulary, expressions, and grammatical structures in isolation. It can be believed that writing is a form-focused or linguistic accuracy-based activity through memorization and rehearsal. Teachers play a crucial role 
in building up students' English writing ability. Whereas, from another belief, this ability is primarily constructed through active self-reflection, peer interaction, and meaning making. It is inferred from this belief that writing may be a complex cognitive process of multiple steps, and it is a social activity in terms of interaction among writers.

\subsection{Beliefs in the Teachers' Roles and Teaching Orientations}

For Richards, Gallo, and Renandya [26], teachers' beliefs can also be reflected through views about teacher roles and how teachers define their work. According to Zheng [27], "people hold different conceptual orientations towards teaching and the role of teachers" (p. 76). Then, Zheng exemplifies that "some teachers may regard language teaching as a process of information transmission, while others think of the teacher as a facilitator of language learning" (p. 76). Additionally, Chai [28] conceptualizes teachers' beliefs into the knowledge transmission and construction views. Based on this domain of teachers' beliefs, what teachers think about models of effective instruction, instructional approaches, teaching roles, and appropriate classroom activities [25] can be grasped.

\subsection{Teachers' Classroom Practices of Writing Instruction}

Another paper's focus was pertinent to the actual picture of writing instruction in the Vietnamese high school context. To make their classroom practices successful, writing teachers need to fully capture writing knowledge such as writing levels, aspects, and teaching approaches; besides, teachers' roles should be critically viewed.

\subsection{Focus on Writing Levels}

Learners usually learn and practice writing, the art of putting words together [29], according to two levels: sentential level (i.e., between one and two sentences) and textual level (paragraphs or text genres).

Harmer [29] opines that writing at the sentential level is often used for grammar reinforcement by producing similar sentences based on sentence models and examples. Referring to the reality of teaching English at the Vietnamese high school, writing at a sentential level often occurs in grammar classes in "E. Language Focus" sections of English 10, English 11 and English 12, which are the coursebook series used to teach English subjects at high school. In these classes, sentence writing mainly deals with the accuracy of grammatical structures through students doing some exercises such as transformation, matching, arrangement, etc. Naturally, writing at this level in Vietnamese high schools focuses primarily on grammar acquisition rather than writing skill development in its own right.

On the textual level of writing, Dikilitaş [30] reveals it is "functional features of cohesion at surface level leading to coherence at deep structure" (p. 5). In other words, for this level, the writers have to organize their ideas into cohesive and coherent paragraphs and texts. Regarding writing at the textual level, since writing is a means of communication, it "fulfills a set of communicative needs, and accomplishes particular purpose" [31], (p. 27). Texts underlie different genres or text types. In the "D. Writing" sections, students are exposed to different text types when they learn writing English: for example, narrative or descriptive paragraph, letters, etc.

\subsection{Focus on Writing Aspects}

In An Introduction to Applied Linguistics, Schmitt [32] states that writing involves the cycle of three aspects, i.e., relational aspect, strategic aspect, and textual aspect.

To the relational aspect, writing always necessitates social contexts under which written expression and communication take place [31,32]. From the researcher's perspective, writing is purposeful at first, which is used to achieve communicative goals (e.g., conviction, invitation, report); secondly, writing is contextual, attached to particular social situations (e.g., school, family, society, etc.). Therefore, learner writers should be required to own "genre knowledge" [32]. Consequently, one useful means for enhancing student 
writers' social awareness is that teachers use suitable authentic materials in the language classroom [33].

As for the strategic aspect, Schmitt [32] advocates that writers must draw on various strategies to comprehend the given topic and respond to it in a written form. It means that learner writers must handle certain ways to compose their written text according to the given rhetorical context. Regarding writing teachers, Schmitt then asserts that understanding the strategic aspect of writing is vital for writing teachers as it enables them to teach writing (practice-driven) in lieu of teaching about writing (theory-driven). Alternatively saying, teachers should instruct students how to write (i.e., the steps to manipulate their writing such as planning, organizing ideas, choosing linguistic features) instead of merely linguistic knowledge.

To the textual aspect, besides constructing the meaning of their ideas, writers also need to build up the meaning that helps the readers navigate through the text [32]. It is obvious that writers should note whether readers can understand what to be written by the writers or not. Put simply, writing texts should be assured of their coherence and cohesion.

\subsection{Focus on Teaching Approaches}

As Uddin [22] requests, "teachers need orientation regarding different approaches to teaching writing other than what they follow along with a practical demonstration on how each approach functions" (p. 119). Therefore, a critical review of instructional approaches for writing lessons is necessary. Of all instructional approaches, the most prominent ones consist of the product approach, the process approach, and the genre-based approach.

The product approach encourages students to produce a final product similar to a model text, which is normally provided by teachers [34]. It is inferred that the role of teachers in this approach is a provider of model language and guided exercises and corrector of errors when the final error-free product is created. In closing, grammar, vocabulary, and mechanics are highly emphasized instead of content, process, audience, and purpose of writing [35]. Clearly, the writing product approach is buttressed by the marriage of structural linguistics and behaviorist learning theories.

Converse to the more traditional product-focused approach, the process approach is currently being adopted in English language writing education [34], by which teachers encourage students to experience writing via different steps [29] such as invention strategies, multiple drafts, and formative peer feedback [36]. Thus, from the researchers' perspective, the process approach to teaching writing embraces eminent traits of cognitive learning and social constructivism theories.

The genre-based approach emphasizes the importance of exploring the social and cultural context of language use on a piece of writing [37]. Put simply, writing is used as a vehicle for achieving particular communicative goals in accordance with specific social situations. The teacher can develop an understanding of the social function and purpose of the text by eliciting students to think: What is the text about? Who wrote it, and who will read it? Why is the text written? [38]. Derewianka [39] enumerates six main school text types according to their primary social purposes: (1) Narratives: tell a story, usually to entertain; (2) Recount: To tell what happened; (3) Information reports: provide factual information; (4) Instruction: tell the listeners or readers what to do; (5) Explanation: Explain why or how something happens; (6) Expository texts: Present or argue a viewpoint. To recap, the genre-based approach is inherently bolstered by the three educational theories, i.e., behaviorist learning, cognitive learning, and social constructivism.

\subsection{Focus on Teachers' Roles}

Richards and Rodgers [40] claim that teacher roles are related to a set of issues such as the kind of job teachers are required to fulfill, the extent of control an educator has over the learning practices adopted, or the trends of interaction that come about between learners and educators. It can be inferred that based on the particular subject matter and learner characteristics, teachers need to determine which roles to be fulfilled and to what extent 
these roles manifest. In the fourth edition book "The Practice of English Language Teaching," Harmer [41] presents several terms to describe a particular kind of teacher. Nevertheless, he categorizes these terms into two main groups, i.e., knowledge transmitter and facilitator.

To the former, teaching is viewed as a "performer" [41]. Ihedioha [42] describes that a knowledge transmitter "emphasizes the need to give pupils basic facts and information before they can be expected to think for themselves" (p. 36). Afterward, he argues that with this deductive model, "so much of the work of learning is controlled and directed by the teacher" (p. 37), and therefore "some students will do better under learning conditions that are fewer teachers directed and controlled" (p. 37). However, the extent of this role should be taken into consideration. According to a personal view, the researchers expect that the deductive role needs combining with others flexibly so that students' learning may be effectively manifested.

To the latter, Harmer [41] uses "facilitator" to describe another kind of teacher, "who fosters learner autonomy through the use of group work and pair work, and by acting as more of a resource than a transmitter of knowledge" (p. 108). As a facilitator in writing classrooms, teachers should perform some following typical tasks: (1) Organizing students to do various writing activities [41], such as brainstorming [43], (2) Provoking the students into having ideas when they get stuck [41], (3) Organizing writing activities collaboratively through the use of pair-work and group work [44], such as peer feedback $[17,45-48]$ (4) Create a favorable environment for students to write a lot [22]. Admittedly, when the teacher role is transferred from a knowledge transmitter to a facilitator, students become almost proactive in their learning to write. They actively participate in writing activities in a cooperative environment. In reality, is it feasible that high school teachers simply act as facilitators in their writing classroom instead of knowledge transmitters? Do teachers expect a harmonious combination between the two roles? Writing teachers have got to consider these inquiries carefully.

Providing feedback is an indispensable part of writing development, and there cannot be denied the necessity of teachers' providing feedback on students' writing. In terms of time, teachers' feedback provision can take place at two phases of writing lessons, i.e., While Writing and After Writing. In terms of types, feedback can be both on the form (e.g., grammar and mechanics) and content of writing (e.g., organization, ideas, and amount of detail) [49].

\subsection{Transition from Beliefs to Practices}

Not only have teachers' beliefs about writing and its teaching constantly been probed, but relationships between teachers' beliefs and their actual classroom practices of writing instruction have also been published [21,22,24]. For example, Uddin's [22] study yielded its findings that although the participants believed that writing is a process and student writers should follow several stages to write such as gathering ideas, planning, revising, and drafting, they were unable to practice in classrooms, which they believed for some reasons including large classrooms, exam-oriented culture, demands of syllabus completion on time, low-level students, and time constraints. Similarly, Nigam [24] examined how beliefs impact classroom writing instruction at Auburn Elementary School in the United States. As what has been reported in this case, the teacher believed students needed an understanding of the components of the process (e.g., brainstorming, planning, rough draft, final draft), which she modeled in her instruction. Evidently, the participant highly employed process orientation to teaching writing in her classroom. Still, she admitted that in practice, beliefs were not always aligned with writing instruction for some reasons such as demands of the assessment, professional development availability, challenges of the classroom context, and level of preparation for teaching writing. Additionally, in Gaitas and Martins [23], both the form and content of writing were highly prized by the primary teachers; then, these beliefs were consistently transferred into classroom organization in which the participants organized writing activities in various configurations such as solo, 
pair, or small group. Clearly, the relationship between teachers' beliefs and practices has been open to debate, which is often impacted by multiple factors.

In academia, discrepancies between teachers' beliefs and the reality of their classroom practices have been widely debated. Khader [50] advocates that teachers have a set of complex belief nests that are sometimes not transferred into their classroom practices for various complicated reasons such as (a) the teachers' beliefs cannot necessarily have a huge impact on the way they teach, (b) they are required by law to teach certain things that may go along with beliefs, and (c) teachers must compensate for the disjunction between their personal beliefs and realities of classroom restrictions, as what teachers believe and what they actually do are quite different. In the field of writing instruction, Melketo [21] adapts Borg's [15] model, the most salient conceptual framework of factors impacting the manifestation of these beliefs in classroom practices (see Figure 1).

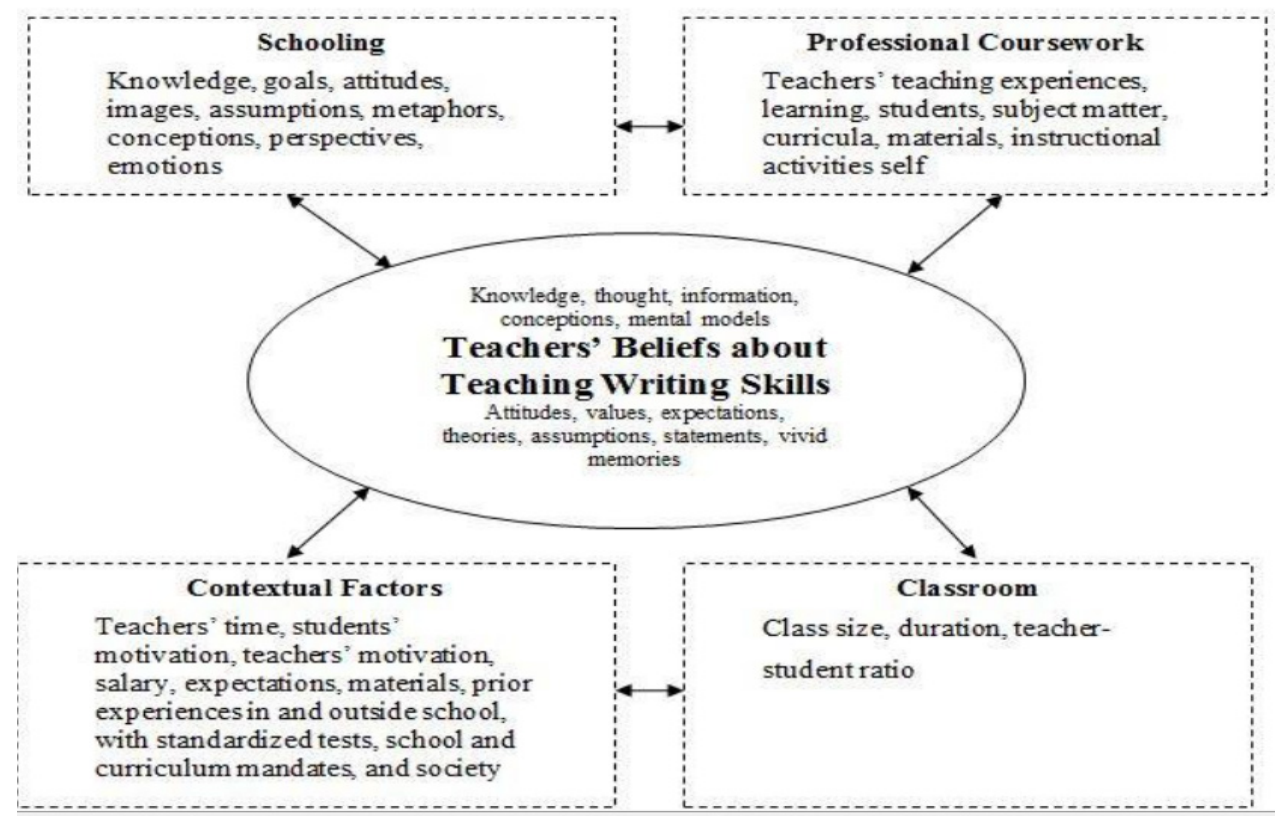

Figure 1. Conceptual framework of factors impacting the manifestation of teacher's beliefs in classroom practices.

Particularly, Borg' [15] model reveals the four core factors that impact writing teachers' manifestation of their beliefs in classroom practices, including (a) schooling (e.g., certain knowledge, subject goals), (b) professional coursework (e.g., teachers' experience, curricular, materials), (c) contextual ingredients (e.g., teachers' time, students' motivation, examination demands), and (d) classroom (e.g., classroom size, duration, teacher-student ratio). The purpose of this paper is to investigate whether there are any differences between the teachers' writing instruction beliefs and their classroom practices at selected high schools in Ho Chi Minh City, Vietnam. The null hypothesis is that the teachers' writing instruction beliefs are consistent with their classroom teaching practices.

\subsection{Research Questions}

1. What are the teachers' beliefs in teaching writing skills, including the importance of writing skills, the merits and nature of writing, teachers' roles, and teaching activities?

2. What are the teachers' real writing practices in their classrooms in terms of pre-writing activities, while-writing activities, and post-writing activities?

3. Are there any differences between the teachers' writing instruction beliefs and their classroom practices? 


\section{Materials and Methods}

\subsection{Subjects}

In this paper, the picture of the high school teachers' beliefs and practices of writing instruction in the Vietnamese context was illuminated at eight selected public high schools with the participation of 76 EFL full-time teachers. Most of the participants were female teachers (63 out of 76). Their ages varied between 22 and above 50 years old, and roughly one-third of them were low-experienced teachers (22 out of 76) with only 1 to 5 years in service.

\subsection{Design and Instruments}

This study was grounded in a survey design to collect sufficient data for the research interest. Specifically, the researchers decided to employ a questionnaire, which is known as one of the easiest methods to manage even with large numbers of subjects [51] and one of the most useful tools to exploit the subjects' attitudes, beliefs, and perceptions. This numerical tool consisted of 39 items, covering three distinct sections, i.e., beliefs (Items 1-18), classroom practices (Items 19-38), and alignment between these two dimensions (Item 39). These items excluding Items 1, 2, and 39 were rated on a five-point Likert scale, including $1=$ totally disagree, $2=$ disagree, $3=$ uncertain, $4=$ agree, and $5=$ totally agree .

\subsection{Data Collection and Analysis}

On the agreed dates, the questionnaire copies that had been translated into Vietnamese beforehand were delivered to 76 participants. On the receipt of questionnaires from the respondents, the researcher found that all 76 copies were valid and accepted. Finally, the researcher employed Statistical Package for the Social Sciences (SPSS) version 20.0 to analyze the descriptive statistics of the collected questionnaires in terms of mean (M) and standard deviation (SD). Finally, the researchers reported the analyzed data based on pre-determined themes, including the teachers' beliefs, practices, and alignment.

\section{Results and Discussion}

The results of this study would be presented under the light of the two following research questions.

Research question 1 : What are the teachers' beliefs in teaching writing skills, including the importance of writing skills, merits and nature of writing, teachers' roles, and teaching activities?

In order to respond to the first research questions, the researchers analyzed and categorized the data into themes.

\subsection{Teachers' Beliefs \\ 3.1.1. Beliefs in Importance of Writing Skill}

As can be seen from Figure 2, most of the teacher participants agreed that writing is as important as other language skills in the ELT secondary curricular (Item 1, 89\%). Apparently, this belief can be derived from the target ELT curriculum prescribed by MOET [52]. To elaborate, Nguyen [53] claims that the textbook series and ELT curricula for three-grade high school level mandated by Vietnamese MOET equalize the focus and time allocation of all four language skills, which look more communicative than the old series focusing almost on reading and grammar. In fact, writing was not "equally treated" to other language skills and language areas until it became an integral part of the new-format National GCSE examination. Nevertheless, this growing grasp of the importance of writing in language learning by the selected teachers is a positive sign, which may drive them to rethink and modify their roles and teaching orientations as well in their high school contexts.

Figure 3 elucidates the importance of writing at the high school level for some reasons (Item 2). On the one hand, most of the participants (89\%) believed that writing skills would help their students succeed in examinations and the new-format National GCSE examination as a typical case. On the other hand, only approximately half of those surveyed 
(55\%) agreed that writing could help high school students practice collecting and organizing ideas. It is clearly interpreted that writing skill is only paid attention to by these teachers until it is compulsorily required for the ELT curriculum and the examinations rather than being a so-called communicative medium, which focuses on meanings to be conveyed through written texts. However, suppose the teaching of writing skills at high schools is paid attention in response to such a temporary examination demand. In that case, students writing ability might be restricted to much extent due to the coping-with strategies of the teachers, such as having students learn the sample texts by rote. To make writing instruction optimum, high school teachers need to be aware of the importance of writing skills in their own right.

\section{Degree of Importance of Writing Skill under Teachers' Beliefs}

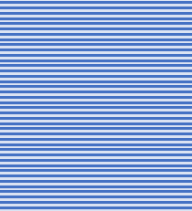

$89 \%$

- Less important than other language skills

- As important as other language skills

- More important than other language skills

Figure 2. Teachers' beliefs in importance of writing.

\section{MERITS OF WRITING UNDER TEACHERS' BELIEFS}

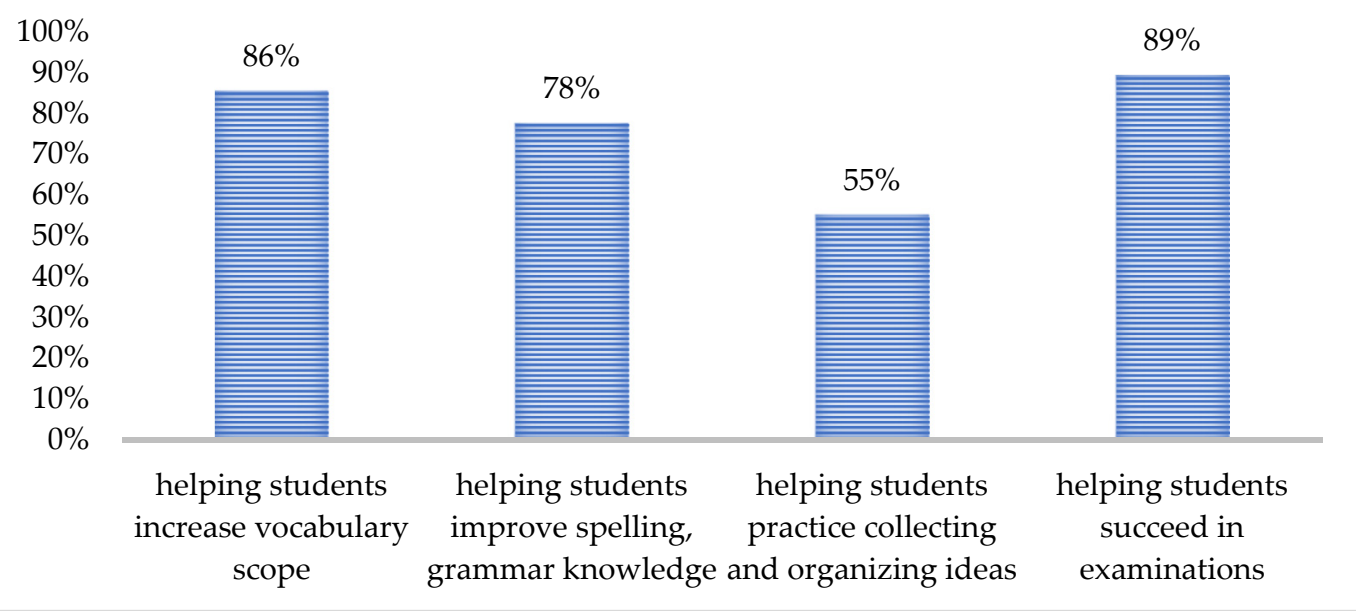

Figure 3. Teachers' beliefs in merits of writing.

The value of writing was also highly appreciated when it was helpful for students to increase vocabulary scope ( $86 \%$ of the respondents) and improve their spelling and gram$\operatorname{mar}(78 \%$ of the respondents). Instead of considering writing as one means of exchanging ideas and achieving communicative functions, the respondents reckoned it to recycle lexis and syntactic knowledge. Basically, writing was "unequally treated" to other language skills, even to language areas. Consequently, it could be one of the primary causes leading to a dilemma that the high school students may possess a heap of vocabulary and grammar, but their writing skill has still remained unacceptable so far. In a humorous comparison, construction materials are available (e.g., grammar and vocabulary), but there is a lack of 
house-building techniques (e.g., the procedures to garner and organize ideas for composing written texts). To recap, no matter what the purposes are, it seems somehow positive that writing has been ultimately tackled more equally than before at any rate.

\subsubsection{Beliefs in Nature of Writing Skill}

From the data in Table 1, most of the respondents highly acquiesced that writing at Vietnamese high schools was a form-based activity with the highest extent (Item 3, $\mathrm{M}=4.33, \mathrm{SD}=0.737$ ). It is inferred that they regarded writing as an act of learning and practicing linguistic structures (e.g., grammar, vocabulary, mechanics) and particular textgenre schematic features (e.g., parts of expository, narrative, report, letter) through doing controlled composition tasks (e.g., completion, matching, arrangement). It is clear that text structures and linguistic forms were prioritized to writing ideas or content. Theoretically, this form-based view of the respondents on writing instruction is in agreement with the marriage of structural linguistics and behaviorist learning theories [31]. Specifically, writing is seen as a product constructed from the writer's command of grammar and lexical knowledge; writing development is considered the result of imitating and manipulating models provided by the teacher. Most strikingly, writing as a functional social-based activity was strongly favored by the group of teachers with the second-highest extent (Item $4, \mathrm{M}=4.21, \mathrm{SD}=0.718$ ). While the nature of writing as a form-based activity was most opted by the respondents, it is a positive sign that many of them also believed that writing at high school needs to be purposeful and contextual. It means thinking before writing down ideas. Learner writers need to identify whom they will write for (i.e., the audience) and what (i.e., the purpose). Khanalizadeh and Allami [1] assume that "every successful text will display the writer's awareness of its context" (p. 335), including the audience and the purpose. From Table 1, we can see that the group of teachers consciously considered that writing is a cognitive process-based activity (Item 5, M $=3.97, \mathrm{SD}=0.832$ ). This finding is similar to Uddin's [22] finding that the participants believed student writers should follow several stages to write, such as gathering ideas, planning, revising, drafting, etc., when learning to write. In the same line with the communicative objectives formulated by the Vietnamese MOET that " $[. .$. ] students proactively participate in learning activities and communicative activities creatively and collaboratively" (p. 7), the teachers at selected public high schools supposed that writing should be an interactive social-based activity at high schools in which students would work collaboratively to construct ideas and check linguistic errors to each other (Item 6, M = 3.62, SD = 1.107).

Table 1. Beliefs in nature of writing.

\begin{tabular}{clccc}
\hline Item & \multicolumn{1}{c}{ Statement } & N & M & SD \\
\hline 3 & Writing is a form-based activity & 76 & 4.33 & 0.737 \\
\hline 4 & Writing is the cognitive process-based activity & 76 & 3.97 & 0.832 \\
\hline 5 & Writing is a functional social-based activity & 76 & 4.21 & 0.718 \\
\hline 6 & Writing is an interactive social-based activity & 76 & 3.62 & 1.107 \\
\hline
\end{tabular}

According to Mekki [6], one of the primary causes making writing skills difficult to acquire is that students or teachers still believe that students' good writing ability derives from what they have learned about language and text forms but ignore specific steps and collaborative strategies. However, in this study, a positive thing was found in terms of teachers' beliefs about the nature of writing. Although the teachers at selected high schools still highly believed that language accuracy and text structure are the main concern of writing skills, they also believed that writing should be viewed as a cognitive process and social-based activity. In other words, they perceived that writing skills at the high school level are restricted by separate language and text forms. It also encourages students to develop cognitive process and functional awareness as well as collaboration. 
In short, it is indicated that the high school teachers' beliefs about the nature of writing were not very narrow but quite eclectic views, that is, a combination of formoriented, process-oriented, and social-oriented views, regardless of the form-oriented view still being highly opted. According to Khanalizadeh and Allami [1], "teachers who chose [ . . . ] all three orientations were considered to have multiple orientations" (p. 341); therefore, the respondents of this study were multiple-oriented in the view of the nature of writing/learning writing at high schools. Schmitt [32] posits that writing should involve three interrelated aspects: relational, strategic, and textual. In terms of the relational aspect, writing should be embedded in a particular social situation and used to achieve certain communicative goals (i.e., functional social-based view). In terms of strategic aspects, writing requires writers to possess the steps to follow, such as planning, organizing ideas, and choosing appropriate linguistic features (i.e., cognitive process-based view). In terms of textual aspects, writing asks writers to use legible discourse features (e.g., vocabulary, grammar, sentence patterns, text structures) to guarantee coherence and cohesion of writing, helping the readers navigate the meanings of the text (i.e., form-based view).

\subsection{Beliefs in Teachers' Roles}

On the one hand, the teachers widely favored the role of a knowledge transmitter to the highest extent (Item 7, M = 4.47, SD =0.621). This is in line with what Nguyen [54] suggests when discussing teaching EFL writing in the Vietnamese context: "language teachers need to provide learners with certain input before asking them to write." She further explains, "input drives acquisition, which should be put ahead of teaching in any approach of language instruction that wants to be successful." Accordingly, the researcher thinks that direct knowledge transmission or comprehensive input (e.g., grammatical items, key expressions, text structures) when teaching writing is essential, especially for high school students. However, suppose that so much of the work of learning is controlled and directed by the teacher. In that case, students may confront some difficulties in free writing, which has received more attention in recent new-format examinations.

On the other hand, Table 2 reveals that these high school teachers did not seem to believe in the effectiveness of the main teacher role as a facilitator in their current writing classroom (Item $8, \mathrm{M}=3.18, \mathrm{SD}=1.092$ ). This ignorance may be explained that in order to fulfill this role successfully, the teachers are required to conduct several challenging learner-centered tasks; for example, organizing students to do various writing activities [41]; provoking the students into having ideas when they get stuck [29]; organizing writing activities collaboratively through the use of pair or group work [44]; and creating a favorable environment for students to write a lot [22]. However, if successfully fulfilling in the context of high schools, facilitators can motivate students to learn writing, enhance learner autonomy [41]; as a result, their writing ability can be independently developed. Nevertheless, without language input provided by knowledge transmitters, these students could hardly learn this productive skill effectively due to such a minimal curriculum, consisting of sixteen classes and forty-five minutes per class.

Table 2. Beliefs in teachers' roles.

\begin{tabular}{clccc}
\hline Item & \multicolumn{1}{c}{ Statement } & $\mathbf{N}$ & $\mathbf{M}$ & SD \\
\hline 7 & $\begin{array}{l}\text { The teacher should primarily perform the role } \\
\text { of a knowledge transmitter }\end{array}$ & 76 & 4.47 & 0.621 \\
\hline 8 & $\begin{array}{l}\text { The teacher should primarily perform the role } \\
\text { of a facilitator only }\end{array}$ & 76 & 3.18 & 1.092 \\
\hline 9 & $\begin{array}{l}\text { The teacher should perform both knowledge } \\
\text { transmitter and facilitator }\end{array}$ & 76 & 4.39 & 0.655 \\
\hline
\end{tabular}

Given such a situation mentioned above that each separate role has its negative effect, the respondents strongly believed that a combination of these two roles mentioned above could manifest their high school students' writing ability as much as possible (Item 9, 
$\mathrm{M}=4.39, \mathrm{SD}=0.655)$. To elaborate, flexibility in teacher roles may lead students to acquire language input sufficiently provided by teachers and produce writing output meaningfully and independently by themselves. Clearly, in terms of teacher roles, the participants preferred Chai's [28] perspectives, i.e., knowledge transmission and construction, in a combined way.

\subsection{Beliefs in Teaching}

Teaching writing is an act of different steps or procedures, involving (a) the choice of instructional activities, (b) the selection and employment of instructional materials, (c) the choice of corrective feedback, and (d) the encouragement of students' extensive practice. Accordingly, teachers' beliefs about teaching writing may involve these dimensions. From the data in Table 3, it is apparent that the selected participants strongly held their beliefs about form-based orientation in teaching writing for high school students (Item 10, $\mathrm{M}=4.54, \mathrm{SD}=0.621$ ) through teachers analyzing model texts on the basis of linguistic features and genre schematic structures before students writing. Positively, functional social-based orientation to teaching writing was highly appreciated by the respondents (Item $11, \mathrm{M}=4.21, \mathrm{SD}=0.805$ ) when they thought that teachers should raise students' awareness of the social function and purpose of the text (e.g., narrating, reporting, etc.). Obviously, the high school teachers still followed traditional beliefs, that is, the knowledge transmission view. The researchers agreed that providing the sample texts and developing students' understanding of the social functions of these texts should be first practiced in writing instruction for many low-level high school students. In addition to the aforementioned stable beliefs on the choice of form-based and functional social-based orientations to teaching writing at the high schools, the teachers were united in their belief that they should guide students in how to compose a text independently (Item $12, \mathrm{M}=3.89$, $\mathrm{SD}=0.798$ ) as well as organize collaborative activities among students in pairs/groups (Item 13, M = 3.74, SD = 1.063). Personally, the researchers posited that the teachers need to give their students an understanding of the steps to manipulate their writing so that they become independent writers in different situations, even in examinations. At the same time, interaction that is built up among students during writing classes can bring out considerable lucrative outcomes; for example, if students are encouraged to participate in the activities of meaning exchange with their peers in learning writing, it can help student writers have positive reinforcements about the knowledge of linguistics, content, and ideas in composing texts [55]. Thus, the participating teachers had multiple orientations to teaching writing at their high schools. Simply, the Vietnamese teachers relied on a combination of product, process, and genre-based approaches in their writing instruction. Nevertheless, the teachers' pedagogical beliefs about instructional activities mostly followed the view of knowledge transmission rather than that of knowledge construction. Ultimately, using different orientations to teaching writing skills is necessarily essential in the high school context since, according to what Uddin [22] recommends, "teachers need orientation regarding different approaches to teaching writing other than what they follow along with a practical demonstration on how each approach functions" (p. 125).

Another component of teachers' pedagogical beliefs is the selection and employment of instructional materials, which are an indispensable part of the teaching process [56]. According to Nguyen [53], the activities in "D. Writing" sections in the textbook series mandated by the Vietnamese MOET do not target readership and writing purposes. Thus, it should be necessary to utilize authentic materials that have been produced to fulfill some social purposes in the language community [57]. Expectedly, most teachers positively believed that they should use authentic supplementary materials such as newspaper articles, letters, and videos besides the prescribed textbooks for their writing class (Item 14, $\mathrm{M}=4.54, \mathrm{SD}=0.720$ ). This belief was in agreement with the prescription of the Vietnamese MOET that " ... teachers employ supplementary materials to motivate students" (p. 7). If a teacher uses suitable authentic materials in the language classroom, it motivates students because these are more interesting and inspiring than artificial materials. In fact, 
using authentic materials in writing instruction brings about some considerable benefits. First, these real-life materials motivate students to learn to write much when they are exposed to interesting teaching resources such as audio, visual, and printed materials [57]. Furthermore, since these resources are designed for real-life use for interactional and transactional purposes [33], it is believed that these genuine materials can help students develop an understanding of the social function and communicative purpose of the text to be written effectively, which is based on the view of writing as functional social-based activity. Thereby, high school teachers should be encouraged to employ authentic materials and textbooks to help their students yield much improvement in their writing ability, including motivation and social awareness of writing text.

Table 3. Beliefs about teaching.

\begin{tabular}{|c|c|c|c|c|}
\hline Item & Statement & $\mathbf{N}$ & $\mathbf{M}$ & SD \\
\hline 10 & $\begin{array}{l}\text { The teacher should study model texts on the } \\
\text { basis of linguistic features and genre } \\
\text { schematic structures before students write. }\end{array}$ & 76 & 4.54 & 0.621 \\
\hline 11 & $\begin{array}{l}\text { The teacher should raise students' awareness } \\
\text { of the social function and purpose of the text. }\end{array}$ & 76 & 4.21 & 0.805 \\
\hline 12 & $\begin{array}{l}\text { The teacher should guide students on how to } \\
\text { compose a text. }\end{array}$ & 76 & 3.89 & 0.798 \\
\hline 13 & $\begin{array}{l}\text { The teacher should set up collaborative } \\
\text { activities among students in pairs/groups. }\end{array}$ & 76 & 3.74 & 1.063 \\
\hline 14 & $\begin{array}{l}\text { The teacher should use authentic } \\
\text { supplementary materials (e.g., newspaper, } \\
\text { letters, stories) besides textbooks for writing } \\
\text { class. }\end{array}$ & 76 & 4.54 & 0.720 \\
\hline 15 & $\begin{array}{l}\text { The teacher should create a favorable } \\
\text { environment for students to write a lot. }\end{array}$ & 76 & 4.49 & 0.774 \\
\hline 16 & $\begin{array}{l}\text { The teacher should provide corrective } \\
\text { feedback on students' language use } \\
\text { (vocabulary, grammar, mechanics). }\end{array}$ & 76 & 4.03 & 0.838 \\
\hline 17 & $\begin{array}{l}\text { The teacher should provide corrective } \\
\text { feedback on students' idea development } \\
\text { (coherence and cohesion). }\end{array}$ & 76 & 3.45 & 0.855 \\
\hline 18 & $\begin{array}{l}\text { The teacher should provide corrective } \\
\text { feedback on students' both language use and } \\
\text { idea development. }\end{array}$ & 76 & 4.34 & 0.758 \\
\hline
\end{tabular}

It is said that practice makes perfect. In other words, it is important that teachers should establish several chances for their high school students to practice writing much more. Teachers could hardly offer enough chances for their students to practice writing inside the classroom [47]. Thus, Uddin [22] argues that students should be required to be engaged in out-of-class writing activities, since the steps of the writing process could not be fully accomplished inside the classroom. Positively, the data in Table 3 reveal that the participants widely agreed that they should create a favorable environment for students to write a lot (Item $15, \mathrm{M}=4.49, \mathrm{SD}=0.774$ ) so that students could manipulate the stages of the writing process such as idea brainstorming, idea organizing, and appropriate linguistic selecting by themselves. Succinctly stated, assigning students to practice writing on a similar topic and text types outside the classroom is an ideal way, as "practice makes perfect." Especially, the cognitive processes through writing activity can be much more practiced in a comfortable way, as the steps of the writing process could not be entirely accomplished inside the classroom where there exists a temporal limit and a rigid curriculum. 
Often happening during or after students writing, the provision of correct feedback by the teachers is an indispensable component of the teaching process, contributing to students' writing development. There are two orientations to providing corrective feedback [49], including form accuracy and content fluency. It is apparent from the above table that to help students enhance their writing ability, the majority of the teacher participants strongly believed that providing corrective feedback on both language use and idea development is the most optimum way (Item $18, \mathrm{M}=4.34, \mathrm{SD}=0.758$ ). However, the participating teachers preferred providing corrective feedback on students' language use (Item $16, \mathrm{M}=4.03$, $\mathrm{SD}=0.838$ ) to their idea development (Item $17, \mathrm{M}=3.45, \mathrm{SD}=0.855$ ). To some extent, it seems that the teachers still favored form-based orientation rather than a meaning-making process-based one, even in the act of providing written feedback. The teachers' belief in providing written feedback was consistent with their beliefs about the importance of writing toward high school students mentioned earlier. Specifically, writing was believed to be helpful for students to increase vocabulary scope as well as improve their spelling and grammar rather than practice gathering and organizing ideas. Nevertheless, the teachers' belief about a combination of both form-based and meaning-making processbased orientations for their providing corrective feedback was ultimately found. To recap, it is essential for the teachers to suggest their corrective feedback on the overall quality of students' writing because writing ability refers to accurate language use and fluent idea development. In other words, when correcting students' writing, the teachers should focus on both sentential and textual levels.

The following section presents the results of the second research question.

Research question 2: What are the teachers' real writing practices in their classrooms in terms of pre-writing activities, while-writing activities, and post-writing activities?

To provide answers to this research question, all the teachers' classrooms practices, including pre-writing activities, while writing activities, and post-writing activities were analyzed.

\subsection{Teachers' Classroom Practices}

\subsubsection{Pre-Writing Phase}

As can be seen from Table 4, the teacher participants usually provided their students with a sample text of writing (Item 19, M = 3.91, SD = 0.751) before they were asked to write their own texts. This act was consistent with what Nguyen [54] posits: that language teachers need to provide learners with certain input before asking them to write. However, this model writing text was much more frequently extracted from the textbooks (Item 20, $\mathrm{M}=4.01, \mathrm{SD}=0.902$ ) rather than from authentic supplementary materials (Item 21, $\mathrm{M}=2.59, \mathrm{SD}=0.824)$. As discussed earlier, authentic materials play a pivotal role in building students' awareness of social functions and contexts of what to be written; therefore, the teachers should be encouraged to employ these kinds of materials for their teaching.

After introducing the model writing text, the respondents usually highlighted its linguistic features (e.g., vocabulary, grammar) and genre schematic structure (e.g., parts of a particular text type) (Item $23, \mathrm{M}=4.10, \mathrm{SD}=0.778$ ) as well as often had them do a few controlled exercises of these highlighted linguistic features and genre schematic structure such as filling in, matching, ordering, etc. (Item $24, \mathrm{M}=3.69, \mathrm{SD}=0.775$ ). A positive finding was ultimately found that the teachers usually utilized a set of comprehension questions in order for students to capture the function and context of the model text, such as "What is the text about? Who wrote it and who will read it? What the text is written for?" (Item 22, $\mathrm{M}=3.88, \mathrm{SD}=0.753$ ) It is interpreted that the teachers were much or less focused on the functional social-based nature of writing.

However, it is apparent from this table that the majority of the participants did not often, if any, have their high school students brainstorm to generate ideas before their writing individually (Item $26, \mathrm{M}=2.52, \mathrm{SD}=0.828$ ) as well as in pairs or groups (Item 27, $\mathrm{M}=2.34, \mathrm{SD}=0.873$ ). In theory, brainstorming before starting to write is extremely 
important when it helps student writers grasp what is to be written by themselves; on the contrary, in practice, this activity seems to be neglected.

Table 4. Actual pre-writing activities.

\begin{tabular}{cllll}
\hline Item & \multicolumn{1}{c}{ Statement } & N & M & SD \\
\hline 19 & $\begin{array}{l}\text { Before having students write, I supply a } \\
\text { model text of writing for them to mimic. }\end{array}$ & 76 & 0.91 \\
\hline 20 & $\begin{array}{l}\text { I supply students with a model text of writing } \\
\text { from a textbook. }\end{array}$ & 76 & 4.01 & 0.902 \\
\hline 21 & $\begin{array}{l}\text { I supply students with a model of writing text } \\
\text { from authentic supplementary materials. }\end{array}$ & 76 & 2.59 & 0.824 \\
\hline 22 & $\begin{array}{l}\text { I elicit students some kind of comprehension } \\
\text { questions about the model text: What is the text } \\
\text { about? Who wrote it, and who will read it? What } \\
\text { is the text written for? }\end{array}$ & 76 & 3.88 & 0.753 \\
\hline 23 & $\begin{array}{l}\text { I highlight linguistic features and the genre } \\
\text { schematic structure of the model text. }\end{array}$ & 76 & 4.10 & 0.778 \\
\hline 24 & $\begin{array}{l}\text { I have students do a few controlled exercises } \\
\text { of the highlighted linguistic features and genre } \\
\text { schematic structure: filling in, matching, } \\
\text { ordering, etc. }\end{array}$ & 76 & 3.69 & 0.775 \\
\hline 26 & $\begin{array}{l}\text { Before students begin writing, I let them } \\
\text { brainstorm to generate ideas on the writing } \\
\text { topic individually. }\end{array}$ & 76 & 2.52 & 0.828 \\
\hline $\begin{array}{l}\text { Before students begin writing, I let them } \\
\text { brainstorm to generate ideas on the writing } \\
\text { topic in pair or group. }\end{array}$ & 76 & 2.34 & 0.873 \\
\hline
\end{tabular}

To sum up, for the pre-writing activities, many of the respondents usually offered a writing model text for their students to study first. The teachers subsequently provided an analysis of the model text in terms of its linguistic forms and genre forms. Then, these forms were practiced and manipulated through students carrying out a couple of controlled exercises. Clearly, the form-based orientation to teaching writing was followed in the prewriting phase. Regardless of whether intentionally or not, the functional social-based orientation to teaching writing was ultimately applied in which many teachers asked their students a set of comprehension questions in terms of its social context and communicative functions when the model text was learned. Yet, it is really effective to construct students' social and functional awareness of what to be written when authentic materials are more frequently employed in their writing classroom. This request originally stems from the reality that these lively materials have not had their place in writing classrooms at the selected high schools so far. Noticeably, idea brainstorming in individuals or pairs/groups, one of the writing steps, was not much practiced, if any. Put simply, cognitive process-based and interactive social-based orientations seem to be abandoned in this phase.

\subsubsection{During-Writing Phase}

As Table 5 indicates, the majority of the teachers, after pre-writing activities, usually had their students manipulate the linguistic features (e.g., vocabulary, grammar) and the genre schematic structures (e.g., the distinct parts of a particular text type) as well as the prompts suggested by the textbooks or teachers to construct their freer text (Item 25, $\mathrm{M}=3.86, \mathrm{SD}=1.055$ ). Apart from what is called freewriting, this was still somehow controlled composition tasks. Rather surprisingly, many of the participants revealed that during students' writing, they sometimes moved around their classrooms, helping their students when they got stuck in terms of either language use or ideas (Item 32, M = 3.28, $\mathrm{SD}=0.918)$. Indeed, this kind of interaction between the teachers and their students should 
be adequately expanded in writing classrooms in which the students are still independent writers while the teachers take an active role as facilitators.

Table 5. Actual while-writing activities.

\begin{tabular}{|c|c|c|c|c|}
\hline Item & Statement & $\mathbf{N}$ & M & SD \\
\hline 25 & $\begin{array}{l}\text { I ask students to use linguistic features and } \\
\text { genre schematic structures they have learned } \\
\text { along with the given cues to produce the } \\
\text { product. }\end{array}$ & 76 & 3.86 & 1.055 \\
\hline 28 & $\begin{array}{l}\text { I ask students to outline their own gathered } \\
\text { ideas based on the genre schematic structure } \\
\text { that they have been introduced. }\end{array}$ & 76 & 2.97 & 0.776 \\
\hline 29 & I have students to write more than one draft. & 76 & 2.93 & 0.718 \\
\hline 30 & $\begin{array}{l}\text { I ask students to exchange their first draft and } \\
\text { provide feedback. }\end{array}$ & 76 & 2.55 & 0.855 \\
\hline 31 & $\begin{array}{l}\text { I ask students to improve their first draft } \\
\text { based on teacher feedback and peer feedback } \\
\text { to produce their final draft. }\end{array}$ & 76 & 2.63 & 0.712 \\
\hline 32 & $\begin{array}{l}\text { During students writing, I move around the } \\
\text { class and help when they get stuck. }\end{array}$ & 76 & 3.28 & 0.918 \\
\hline
\end{tabular}

On the contrary, a set of cognitive process-based activities (e.g., outlining, drafting, revising, and so forth) were not actually practiced in writing classrooms at the high schools for this phase. Specifically, not many teachers had their students organize their ideas based on the just-introduced genre schematic structure (Item $28, \mathrm{M}=2.97, \mathrm{SD}=0.776$ ). In other words, the outlining step of the writing process was not much favored by the majority of these teachers in practice. To further elaborate, the low frequency of this activity can stem from the fact that the brainstorming step was not practiced beforehand in the pre-writing phase; moreover, the responses to the writing topics are usually available in the textbooks. It seems apparent that the high school teachers did not frequently have their students write multiple drafts (Item 29, M $=2.93, \mathrm{SD}=0.718$ ) before composing the final product. In addition, this table also reveals that peer feedback among student writers, one of the factors contributing to their writing development, was not practically employed by the greater part of teachers (Item $30, \mathrm{M}=2.55, \mathrm{SD}=0.855$ ). Accordingly, it is clearly found that most of the participating teachers did not lead the students to revise their own texts, which was based on feedback from the teachers and classmates (Item 31, M = 2.63, SD = 0.712).

In closing, most of the recruited teachers still followed the form-based orientation to teaching writing in this central phase during writing activities. It is proved that the teachers frequently asked their students to manipulate the learned linguistic and genre forms to write their own texts in a freer way. On the contrary, there seems to be no explicit emphasis on the process of outlining, drafting, peer feedback, and revision. Put differently, the cognitive process-based and social-based orientations were not practically applied in their writing classrooms. However, the most striking result of this phase was that the teachers sometimes interacted with their students by helping them with language and idea resources.

\subsubsection{Post-Writing Phase}

Table 6 shows that a greater number of the participants only sometimes gave corrective feedback and evaluated their students' writing inside classrooms (Item 33, M = 3.04, $\mathrm{SD}=0.936$ ). The limited frequency of this activity may be easily understood because inviting a couple of students to write their work on the blackboard was really time consuming within such a rigid schooling curriculum in the high school contexts. This was consistent with Corpuz's [19] concern that providing written error correction helps students improve their proofreading skills in order to revise their writing more efficiently but is very 
time consuming. Therefore, it is unsurprising that most of the participants usually asked their students to complete their own texts into notebooks at home due to time constraints (Item $37, \mathrm{M}=4.07, \mathrm{SD}=0.838$ ). Contrary to expectations, most teachers did not frequently create many opportunities for their students to practice writing in a comfortable way, such as assigning another similar topic to their students after each writing class (Item 38, $\mathrm{M}=2.64, \mathrm{SD}=0.778$ ). Essentially, the teachers should let students develop their own writing ability independently in a favorable environment such as at home. This originally emerges from the fact that the basic steps of the writing process were only introduced inside classrooms if any, and not much practiced. Thereby, within an exciting writing topic assigned to homework, it is believed that many high school students can experience some basic writing sub-skills such as gathering appropriate language and ideas, outlining their gathered ideas, drafting and revising, and so on. In other words, practice makes perfect regardless of any schooling level.

Table 6. Actual post-writing activities.

\begin{tabular}{|c|c|c|c|c|}
\hline Item & Statement & $\mathbf{N}$ & $\mathbf{M}$ & SD \\
\hline 33 & $\begin{array}{l}\text { I invite one or two students to write their work } \\
\text { on the board so that I can provide feedback } \\
\text { and evaluate for the whole class to keep track. }\end{array}$ & 76 & 3.04 & 0.936 \\
\hline 34 & $\begin{array}{l}\text { I provide feedback and evaluate students' } \\
\text { writing primarily regarding grammar and } \\
\text { vocabulary accuracy. }\end{array}$ & 76 & 3.92 & 0.744 \\
\hline 35 & $\begin{array}{l}\text { I provide feedback and evaluate students' } \\
\text { writing primarily regarding organization and } \\
\text { idea development. }\end{array}$ & 76 & 3.25 & 0.926 \\
\hline 36 & $\begin{array}{l}\text { I provide feedback and evaluate students' } \\
\text { writing regarding overall quality in terms of } \\
\text { organization, idea development, grammar, } \\
\text { and vocabulary. }\end{array}$ & 76 & 3.79 & 0.943 \\
\hline 37 & $\begin{array}{l}\text { After each writing class, I ask students to } \\
\text { finish their uncompleted text at home. }\end{array}$ & 76 & 4.07 & 0.838 \\
\hline 38 & $\begin{array}{l}\text { After each writing class, I assign students } \\
\text { another similar topic to write at home. }\end{array}$ & 76 & 2.64 & 0.778 \\
\hline
\end{tabular}

Furthermore, the orientations to giving corrective feedback on students' writing were also obviously pointed out. In practice, the majority of the participating teachers preferably responded to their students' writing on the basis of accurate language use (Item 34, $\mathrm{M}=3.92, \mathrm{SD}=0.774)$. Conversely, corrective feedback on the students' fluent idea development was not favorably practiced by many of the respondents (Item 35, M = 3.25, $\mathrm{SD}=0.926$ ). It goes without saying that in the reality of providing their written feedback, almost all of the teachers still concentrated on form-based orientation rather than a meaning-making process-based one. In comparison, this practice was somewhat consistent with the teachers' perceptions about the importance of writing toward high school students. Rather positively, many of the high school teachers in this study revealed that they also usually responded to their students' writing in terms of overall quality (Item 36, M=3.79, $\mathrm{SD}=0.943)$; however, language accuracy was still prioritized above idea fluency so far $\left(\mathrm{M}_{\text {language accuracy }}=3.92 ; \mathrm{M}_{\text {idea fluency }}=3.25\right)$ in practice.

To recap, in the after-writing phase, the teachers sometimes corrected and evaluated their students' writing (e.g., between one and two students) before ending the writing lessons, in which accurate language forms were preferably the focus rather than idea organization. For an out-of-class writing activity, a greater number of the participants usually had their students finish their texts into notebooks instead of assigning them another similar topic for further writing practice. 
The next section presents the results of the third research question, which is the main focus of the current study.

Research question 3: Are there any differences between the teachers' writing instruction beliefs and their classroom practices?

The data to respond to the third research question were included the form-based orientation, process-based orientation, and functional and interactive social-based orientation.

\subsection{The Alignment between Beliefs and Classroom Practices}

Whether the classroom instructional practices of the high school teachers in writing classes were congruent with their beliefs became another inquiry of the paper, which was pertinent to the four orientations or natures of writing with three inferential scale intervals: 1.00-2.60: Low degree, 2.61-3.40: Medium degree, 3.41-5.00: High degree.

As Table 7 illustrates, the form-based beliefs held by most participating teachers were nearly aligned with their practices. Alternatively saying, the product approach was much prevalent in their EFL writing instructional practices at their high schools.

Table 7. Teachers' beliefs and classroom practices.

\begin{tabular}{|c|c|c|c|}
\hline \multicolumn{4}{|c|}{ Form-Based Orientation } \\
\hline Domain & Statement & $\mathbf{M}$ & Degree \\
\hline \multirow{4}{*}{ 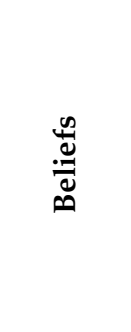 } & Item 3. Writing is a form-based activity. & 4.33 & High \\
\hline & $\begin{array}{l}\text { Item } 7 . \text { The teacher should perform the role of a } \\
\text { knowledge transmitter primarily. }\end{array}$ & 4.47 & High \\
\hline & $\begin{array}{l}\text { Item } 10 . \text { The teacher should study model texts before } \\
\text { students write. }\end{array}$ & 4.54 & High \\
\hline & $\begin{array}{l}\text { Item } 16 . \text { The teacher should provide corrective } \\
\text { feedback on students' language use. }\end{array}$ & 4.03 & High \\
\hline \multirow{5}{*}{ 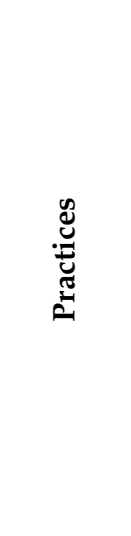 } & $\begin{array}{l}\text { Item 19. Before having students write, I supply a } \\
\text { model text of writing. }\end{array}$ & 3.91 & High \\
\hline & $\begin{array}{l}\text { Item 23. I study the linguistic and genre schematic } \\
\text { structures of the model text. }\end{array}$ & 4.14 & High \\
\hline & $\begin{array}{l}\text { Item } 24 \text {. I have students do controlled exercises of } \\
\text { the highlighted linguistic features and genre } \\
\text { schematic structure. }\end{array}$ & 3.69 & High \\
\hline & $\begin{array}{l}\text { Item 25. I ask students to use the just-learned } \\
\text { linguistic and genre schematic structures and the } \\
\text { given cues to produce the product. }\end{array}$ & 3.86 & High \\
\hline & $\begin{array}{l}\text { Item } 34 \text {. I provide feedback on students' writing } \\
\text { based on grammar and vocabulary. }\end{array}$ & 3.92 & High \\
\hline \multicolumn{4}{|c|}{ Process-based Orientation } \\
\hline Domain & Statement & $\mathbf{M}$ & Degree \\
\hline \multirow{4}{*}{ 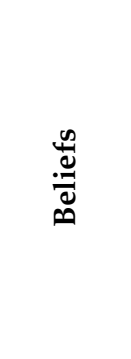 } & $\begin{array}{l}\text { Item } 4 \text {. Writing is a cognitive process-based } \\
\text { activity. }\end{array}$ & 3.97 & High \\
\hline & $\begin{array}{l}\text { Item } 11 . \text { The teacher should guide students on how } \\
\text { to compose a text. }\end{array}$ & 4.21 & High \\
\hline & $\begin{array}{l}\text { Item } 15 . \text { The teacher should create a favorable } \\
\text { environment for students to write a lot. }\end{array}$ & 4.49 & High \\
\hline & $\begin{array}{l}\text { Item } 17 . \text { The teacher should provide corrective } \\
\text { feedback on students' idea development. }\end{array}$ & 3.45 & High \\
\hline
\end{tabular}


Table 7. Cont.

\begin{tabular}{|c|c|c|c|}
\hline \multirow{6}{*}{ 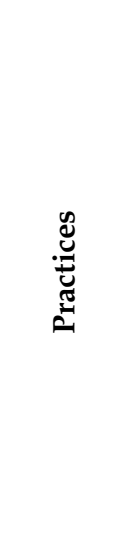 } & $\begin{array}{l}\text { Item } 26 . \text { I let students brainstorm to generate ideas } \\
\text { on the topic individually. }\end{array}$ & 2.52 & Low \\
\hline & $\begin{array}{l}\text { Item } 28 . \text { I ask students to outline their gathered } \\
\text { ideas based on the introduced genre schematic } \\
\text { structure. }\end{array}$ & 2.97 & Medium \\
\hline & Item 29. I have students write more than one draft. & 2.93 & Medium \\
\hline & $\begin{array}{l}\text { Item 31. I ask students to improve their drafts based } \\
\text { on peer feedback. }\end{array}$ & 2.63 & Low \\
\hline & $\begin{array}{l}\text { Item } 35 . \text { I provide feedback on students' writing } \\
\text { regarding idea development. }\end{array}$ & 3.25 & Medium \\
\hline & $\begin{array}{l}\text { Item 38. After each class, I assign students another } \\
\text { similar topic to write at home. }\end{array}$ & 2.64 & Low \\
\hline \multicolumn{4}{|c|}{ Functional Social-based Orientation } \\
\hline Domain & Statement & $\mathbf{M}$ & Degree \\
\hline \multirow{3}{*}{ 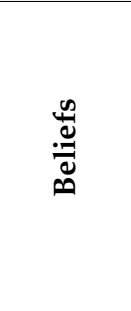 } & Item 5. Writing is a functional social-based activity. & 4.21 & High \\
\hline & $\begin{array}{l}\text { Item } 12 . \text { The teacher should raise students' } \\
\text { awareness of the social function and purposes of the } \\
\text { text (e.g., narrating, reporting, arguing, inviting). }\end{array}$ & 3.89 & High \\
\hline & $\begin{array}{l}\text { Item } 14 . \text { The teacher should use authentic } \\
\text { supplementary materials (e.g., newspaper, letters, } \\
\text { short stories) besides textbooks for writing classes. }\end{array}$ & 4.54 & High \\
\hline \multirow{3}{*}{ 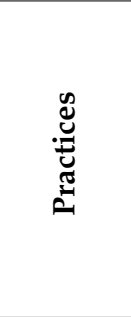 } & $\begin{array}{l}\text { Item 20. I supply students with a model text from a } \\
\text { textbook. }\end{array}$ & 4.01 & High \\
\hline & $\begin{array}{l}\text { Item } 21 \text {. I supply students with a model text from } \\
\text { authentic materials. }\end{array}$ & 2.59 & Low \\
\hline & $\begin{array}{l}\text { Item 22. I elicit some kind of comprehension } \\
\text { questions about the model text: What is the text } \\
\text { about? Who wrote it? Who will read it? }\end{array}$ & 3.88 & High \\
\hline \multicolumn{4}{|c|}{ Interactive Social-based Orientation } \\
\hline Domain & Statement & $\mathbf{M}$ & Degree \\
\hline \multirow{2}{*}{ 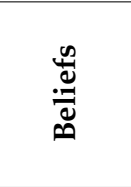 } & $\begin{array}{l}\text { Item 6. Writing is an interactive social-based } \\
\text { activity. }\end{array}$ & 4.21 & High \\
\hline & $\begin{array}{l}\text { Item 13. The teacher should organize collaborative } \\
\text { activities among students. }\end{array}$ & 3.74 & High \\
\hline \multirow{2}{*}{ 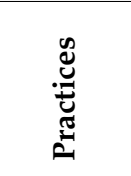 } & $\begin{array}{l}\text { Item } 27 . \text { I let students brainstorm to generate ideas } \\
\text { on the topic in pairs/groups. }\end{array}$ & 2.34 & Low \\
\hline & $\begin{array}{l}\text { Item 30. I ask students to exchange their first draft } \\
\text { and provide peer feedback. }\end{array}$ & 2.55 & Low \\
\hline
\end{tabular}

From Table 7 below, although a large number of the teachers positively believed in the lucrative outcomes of a process-based orientation, there were some tensions between what the teachers believed and what the teachers did. In practice, brainstorming, improvement, or extensive writing were discouraged too much, which was caused by multiple factors such as class duration, students' perceived lack of motivation, and teaching materials.

Based on the data presented in Table 7, the functional social-based nature of writing also received high appreciation from a greater part of teacher participants, i.e., the necessity of raising students' awareness of social functions and communicative purposes of what to be written, and of using authentic supplementary materials. However, this belief was not always aligned with what the high school teachers actually did; that is, the model texts 
were only extracted from the textbooks so far, which was due to the teachers' preparation time and the students' existing proficiency level.

As evidenced in Table 7, the interactive social nature of writing was eventually accepted in the teachers' rooted beliefs, but in practice, this orientation seemed not to be enacted in their writing classrooms: for example, there was a low density of studentstudent interactions. Multiple factors accounted for this lack of congruence between the teachers' beliefs and practices, which were inclusive of class duration and teaching materials' requirement.

Laconically, Item 39 synthesized the possible impacting factors on the relationship between the studied teachers' beliefs and actual classroom practices of EFL writing instruction at their high schools.

As can be shown in Figure 4, the study suggested that the complexities of classroom life could have powerful influences on teachers' beliefs and affect their classroom practices. Several possibilities could explain the mismatch between teachers' beliefs and their actual practices, in which the most influencing factors derived from contextual factors such as students' knowledge and English level (91\%), examination demands (90\%), students' perceived lack of motivation to write $(84 \%)$, and teachers' preparation time $(79 \%)$. In addition, class duration (86\%), curricular $(84 \%)$, and teaching materials $(74 \%)$ were also direct causal factors leading to mismatches between what the teachers believed and what they practically did in the domain of teaching writing at their high school contexts.

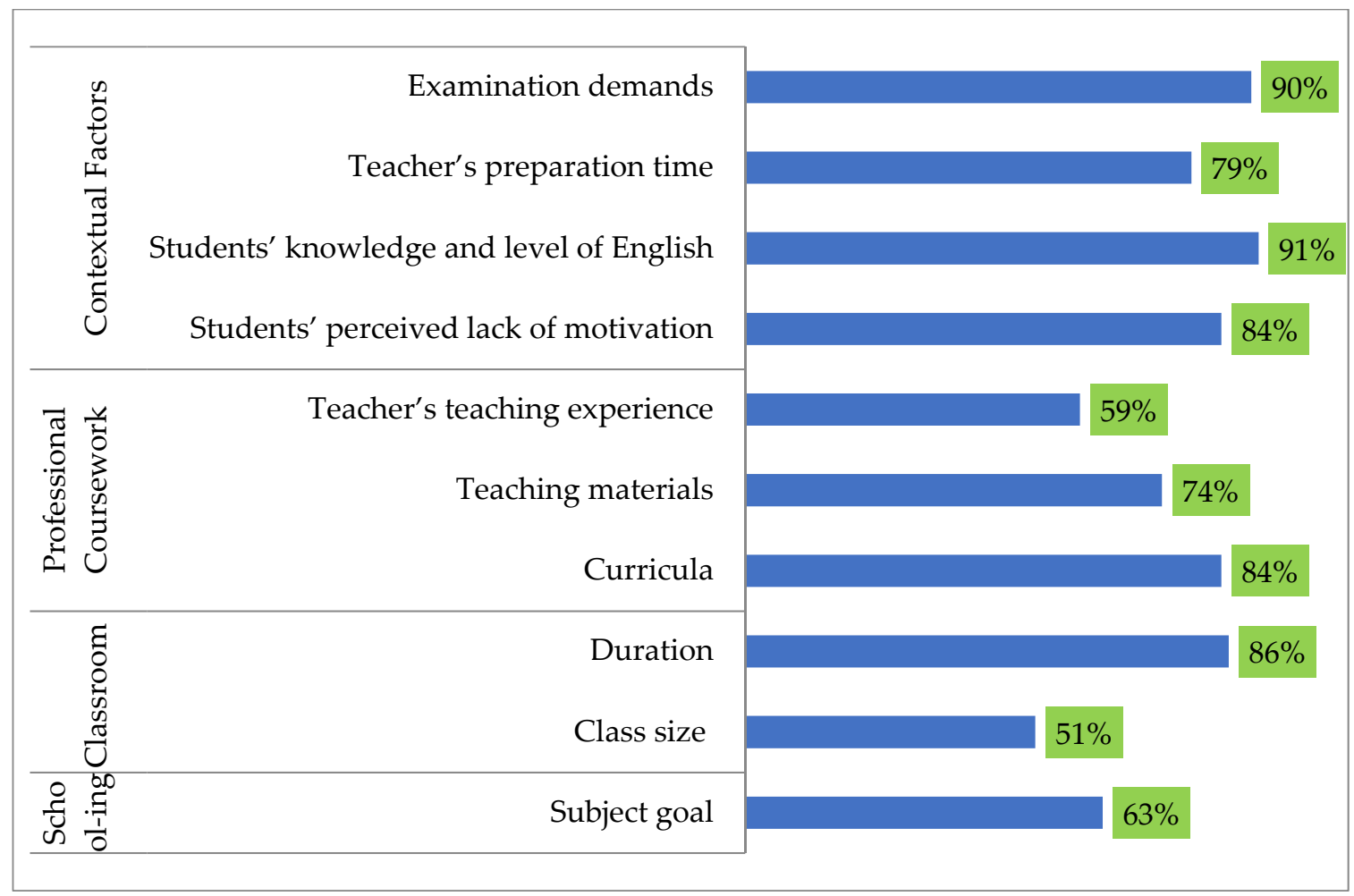

Figure 4. Impacting factors on interplays between teachers' beliefs and practices.

\section{Practical Implications and Conclusions}

As mentioned earlier, the study of teachers' beliefs about writing, its teaching orientations, and the influence they may have on teaching practices, activities, and learning outcomes were conducted to help the Vietnamese high school teachers find effective teaching behaviors [1,47] as well as increase students' achievement in core subject areas such as writing skills $[7,21]$. From the emerging findings of the study, some implications were made as follows. 
Firstly, EFL writing is one of the four skills in English language acquisition; hence, there should be a right perception of its indispensable necessity, especially at the high school level. The teachers' beliefs are the key roles to help the students be successful or not in their writing skills [14], because their beliefs will form their practices in their real teaching [26]. Put simply, writing is not only a means of recycling vocabulary and grammar knowledge, but it also is a useful way to express meanings. If high school students are equipped with basic writing sub-skills in an independent environment, their writing ability will be continually developed at the tertiary level.

Secondly, with respect to the nature of writing, high school teachers should capture that writing is a difficult, sophisticated, social activity and an essential skill for language learners. To elaborate, high school students are incapable of mastering EFL writing skills if they only deal with linguistic accuracy without (a) having opportunities to practice writing independently, (b) having opportunities to work collaboratively with their classmates, as well as (c) identifying the audience and purpose of what is to be written. This has been proved by the very low results of the writing section in the National GCSE examination in recent years. The high school students are often rigidly exposed to sample texts and asked to learn by rote but not handle how to write independently. Several recent studies, such as Pham [45], provided a model for teachers to train Vietnamese students to be effective peer reviewers to help enhance their writing quality. Pham [58] introduced a framework to help students compose their writing collaboratively. Pham and Do [59] and Pham et al. [60] suggested task-based instruction to help Vietnamese students improve their writing outcomes.

Thirdly, in practice, much of the time spent by the teachers in teaching writing to their students has traditionally been devoted to linguistic forms (i.e., vocabulary, grammar) and sometimes genre schematic structures, if any. Although these forms are important prerequisites, encouragement of high school students on writing on their own (i.e., processbased orientation) and being aware of the social function of what they will write (i.e., social-based orientation) is needed much more. If high school teachers only let their students mainly work on linguistic forms, it does not enable students to tell "grammar lessons" apart from "writing lessons" in correct meaning. In other words, because the allocated time for each writing class is rather short, the main duty of each language teacher is to necessarily provide key linguistic and genre forms, eliciting social context and communicative function of specific genres; immediately, the greatest remaining portion of the writing lessons should be devoted to guiding students through basic steps on how to write and do not concentrate on the final product exclusively. Primarily, students have to know how to start writing on their own; from that, students can actively treat any writing examinations by themselves instead of learning by rote. Pham, Huyen, and Nguyen [46] suggested to employ peer feedback in the writing classrooms to help students improve their writing skills.

Next, despite grasping the effectiveness of authentic materials in EFL writing instruction, the reality shows most sample texts were extracted from the textbook series, if available. Time constraints cause this scanty employment of authentic materials. However, regardless of the time constraint factor, high school teachers should try to spend their time preparing at least one simplified text (i.e., content and language suitable for learners) for each text type or text genre they will work on. These authentic texts are more helpful to raise students' social awareness of different genres than the texts composed by Vietnamese writers, which are fully covered in the current textbook series. For this issue, Khalifa et al. [9] suggested that the teachers should always upgrade their theoretical knowledge in order to have appropriate implementations of teaching activities in their classrooms.

Additionally, due to the inadequate duration of each writing lesson inside the classroom and given the demand that high school students need to practice writing more outside the classroom, teachers at high schools should assign their students some interesting topics on the just-learned text genres so that these students will have chances to practice writing 
at home; moreover, the teachers must set deadlines to make sure students will finish their texts, such as those for portfolios. This teaching activity needs to be encouraged due to two reasons. First, the more they write independently, the more their writing ability is improved as much as possible since "practice makes perfect". Pham and Do [61] and Ho and Duong [62] suggested that teachers let their students practice writing as much as possible to reduce their writing errors. Second, when comfortably writing at home, high school students have sufficient time to spend on writing steps such as idea generating, outlining, editing, and so forth; of course, these steps are beforehand guided inside the classroom.

Writing classes are often deemed to be boring, which leads to high school students' perceived lack of motivation; hence, there should be much interaction among students both inside and outside the classroom so that these students can help each other in suggesting ideas and checking linguistic errors $[19,46,48]$. This partly makes writing classrooms become more comfortable when the language teachers do not still play the exclusive authority in their classes. To elaborate, at this time, high school teachers should create flexibility in their roles, not only acting as direct knowledge transmitters but also facilitators, language resources, motivators, and so on.

Last but not at least, in terms of corrective feedback, high school teachers should focus on the overall quality of students' writing (e.g., vocabulary, grammar, content, cohesion, and coherence) rather than only linguistic accuracy (e.g., vocabulary, grammar) $[45,48]$, since the other components of writing such as content, coherence, or cohesion reflect on high school students' cognition development during the process of writing, which refers to students' choosing and organizing ideas. Providing corrective written feedback requires a considerably large amount of time inside the classroom; therefore, the language teachers need to create clear multiple-choice assessment criteria for high school students to self-evaluate and grade their writing performance either inside or outside the classroom.

Author Contributions: Conceptualization, V.P.H.P. and M.H.T.; Methodology, M.H.T.; Data collection, M.H.T.; supervision, V.P.H.P.; Writing the draft, M.H.T. and V.P.H.P.; data analysis, M.H.T.; Writing the final paper, V.P.H.P., Corresponding and editing, V.P.H.P. All authors have read and agreed to the published version of the manuscript.

Funding: This project was funded by Van Lang University, Ho Chi Minh City, Vietnam.

Institutional Review Board Statement: Not applicable.

Informed Consent Statement: Not applicable.

Data Availability Statement: Not applicable.

Conflicts of Interest: The authors declare no conflict of interest.

\section{References}

1. Khanalizadeh, B.; Allami, H. The impact of teachers' belief on EFL writing instruction. Theory Pract. Lang. Stud. 2012, 2, 334-342. [CrossRef]

2. Tran, T.L. Learners' motivation and identity in the Vietnamese EFL writing classroom. Engl. Teach. Pract. Crit. 2007, 6, 151-163.

3. Duong, M.T. A Portfolio-Based Learner Autonomy Development Model in an EFL Writing Course. Ph.D. Thesis, Suranaree University of Technology, Nakhon Ratchasima, Thailand, 2015.

4. Nguyen, T.P.T. Teachers' Beliefs in the Necessity and Feasibility of Fostering Learner Autonomy in Learning Writing. Master's Thesis, Ho Chi Minh City Open University, Ho Chi Minh City, Vietnam, 2019.

5. Asiah, N.; Ardian, E.; Amri, S. A study on the students factor difficulty in writing narrative text at viii grade of mts sabilal muhtadin tembilahan. J-Shelves Indragiri (JSI) 2020, 1, 84-97. [CrossRef]

6. Mekki, C. The Student Awareness of Writing Skill: The Case Study Third-Year Students at Biskra University. Master's Thesis, Biskra University, Biskra, Algeria, 2012.

7. Wei, X.; Zhang, L.J.; Zhang, W. Associations of L1-to-L2 rhetorical transfer with L2 writers' perception of L2 writing difficulty and L2 writing proficiency. J. Engl. Acad. Purp. 2020, 47, 100907. [CrossRef]

8. Barkaoui, K. Teaching Writing to Second Language Learners: Insights from Theory and Research. TESL Rep. $2007,40,14$.

9. Khalifa, A.A.H.A.S.; Ahmed, A.O.A.; Ismael, E.A.A. EFL Teachers' Beliefs and Actual Classroom Practices of Teaching Reading Strategies. Int. J. Sci. Eng. Technol. Res. 2020, 9, 53-59. 
10. Nguyen, L.T.; Newton, J. Pronunciation Teaching in Tertiary EFL Classes: Vietnamese Teachers' Beliefs and Practices. TESL-EJ 2020, 24, n1.

11. Widiastuti, I.A.M.S.; Mukminatien, N.; Prayogo, J.A.; Irawati, E. Dissonances between Teachers' Beliefs and Practices of Formative Assessment in EFL Classes. Int. J. Instr. 2020, 13, 71-84. [CrossRef]

12. Saputra, D.B.; Suherdi, D.; Rodliyah, R.S. Reflective practice as tools to explore in-service teacher's beliefs and classroom practices: Indonesian EFL teachers'voices. J. Appl. Linguist. Lit. 2020, 5, 174-192. [CrossRef]

13. Kraayenoord, C.E.V.; Miller, R.; Moni, K.B.; Jobling, A. Teaching writing to students with learning difficulties in inclusive English classrooms: Lessons from an exemplary teacher. Engl. Teach. Pract. Crit. 2009, 8, 23-51.

14. Le, V.C. Form-Focused Instruction: A Case Study of Vietnamese Teachers' Beliefs and Practices. Ph.D. Thesis, Waikato University, Hamilton, New Zealand, 2011.

15. Borg, S. Teacher cognition in language teaching: A review of research on what language teachers think, know, believe, and do. Lang. Teach. 2003, 38, 81-109. [CrossRef]

16. Pham, V.P.H.; Bui, T.K.L. Genre-based Approach to Writing in EFL Contexts. World J. Engl. Lang. 2021, 11, 95-106. [CrossRef]

17. Pham, V.P.H.; Nguyen, N.H.V. Blogging for Collaborative Learning in the Writing Classroom. Int. J. Cyber Behav. Psychol. Learn. 2020, 10, 1-11. [CrossRef]

18. Farrell, T.S.C. Reflective practice in action: A case study of a writing teacher's reflections on practice. ESL Can. J. 2006, 23, 77-90. [CrossRef]

19. Corpuz, V.A.F.S. Error Correction in Second Language Writing: Teachers' Beliefs, Practices, and Students' Preferences. Master's Thesis, Queensland University of Technology, Brisbane City, Australia, 2011.

20. Abadi, M.K.S.; Marzban, A. Teachers' beliefs and teaching English writing to children and adolescent learners in Iran. J. Acad. Appl. Stud. 2012, 2, 23-31.

21. Melketo, T.A. Exploring tensions between English teachers' beliefs and practices in teaching writing. Int. HETL Rev. 2012, 2, 98-114.

22. Uddin, M.E. Teachers' pedagogical belief and its reflection on the practice in teaching writing in EFL tertiary context in Bangladesh. J. Educ. Pract. 2014, 5, 116-129. [CrossRef]

23. Gaitas, S.; Martins, M.A. Relationships between primary teachers' beliefs and their practices in relation to writing instruction. Res. Pap. Educ. 2015, 30, 492-505. [CrossRef]

24. Nigam, A. The Role of Teacher Knowledge and Beliefs in Classroom Practices: A study of one Fourth Grade Teacher's Writing Instruction. Ph.D. Thesis, Texas Tech University, Lubbock, TX, USA, 2015.

25. Yin, W.K. Teacher Beliefs and Grammar Teaching Practices: Case Studies of Four ESL Teachers. Ph.D. Thesis, The University of Hong Kong, Hong Kong, China, 2006.

26. Richards, J.C.; Gallo, P.B.; Renandya, W.A. Exploring teachers' beliefs and the process of change. APC J. 2001, 1, 42-64.

27. Zheng, H. A review of research on EFL pre-service teachers' beliefs and practices. J. Camb. Stud. 2009, 4, 73-81.

28. Chai, C.S. Teachers' epistemic beliefs and their pedagogical beliefs: A qualitative case study among Singaporean teachers in the context of ICT-supported reforms. Turk. Online J. Educ. Technol. 2010, 9, 128-139.

29. Harmer, J. How to Teach Writing; Pearson Educated Limited: New York, NY, USA, 2004.

30. Dikilitaş, K. The effect of some learner variables and the use of cohesive devices on Turkish nonnative writers' writing quality. $J$. Theory Pract. Educ. 2012, 8, 3-19.

31. Hyland, K. Second Language Writing; Cambridge University Press: Cambridge, UK, 2003.

32. Schmitt, N. An Introduction to Applied Linguistics, 2nd ed.; Hodder Education: London, UK, 2010.

33. Maroko, G.M. The authentic materials approach in the teaching of functional writing in the classroom. In The New Decade and (2nd) FL Teaching: The Initial Phase; Reinelt, R., Ed.; Rudolf Reinelt Research Laboratory EU: Matsuyama, Japan, 2010 ; pp. 71-87.

34. Al-Hammadi, F.; Sidek, H.M. An analytical framework for analyzing secondary EFL writing curriculum: Approaches for writing and preparation for higher education. Int. Educ. Stud. 2015, 8, 59-70.

35. Bae, J. Teaching Process Writing for Intermediate/Advanced Learners in South Korea. Master's Thesis, University of WisconsinRiver Falls, River Falls, WI, USA, 2011.

36. Matsuda, P.K. Exploring the dynamics of second language writing. In Second Language Writing in the Twentieth Century: A Situated Historical Perspective; Kroll, B., Ed.; Cambridge University Express: Cambridge, UK, 2003; pp. 15-24.

37. Hammond, J.; Derewianka, B. Genre. In The Cambridge Guide to Teaching English to Speakers of Other Languages; Carter, R., Nunan, D., Eds.; Cambridge University Press: Cambridge, UK, 2001.

38. Kongpetch, S. Using a genre-based approach to teach writing to Thai students: A case study. Prospect 2006, 12, 30-32.

39. Derewianka, B. Exploring How Text Works; Primary English Teaching Association: Sydney, Australia, 1990.

40. Richards, J.C.; Rodgers, T.S. Approaches and Methods in Language Teaching; Cambridge University Press: Cambridge, UK, 1986.

41. Harmer, J. The Practice of English Language Teaching; Longman: Essex, UK, 2001.

42. Ihedioha, S.A. Effectiveness of transmitter of knowledge and conventional teaching models on secondary school students' achievement on circle geometry and trigonometry. Gen. Math. Note 2012, 12, 35-47.

43. Mohammad, M.F.M.; Hussein, A.A. Enhancing students' motivation to write essays through brainstorming: A comparative study. Int. J. Humanit. Soc. Sci. 2013, 3, 191-196.

44. Storch, N. Collaborative writing: Product, process, and students' reflections. J. Second. Lang. Writ. 2005, 14, 153-173. [CrossRef] 
45. Pham, V.P.H. The Effects of Lecturer's Model e-comments on Graduate Students' Peer e-comments and Writing Revision. Comput. Assist. Lang. Learn. 2021, 34, 324-357. [CrossRef]

46. Pham, V.P.H.; Huyen, L.H.; Nguyen, M.T. The incorporation of qualified peer feedback into writing revision. Asian J. Appl. Linguist. 2020, 7, 45-59. Available online: https://caes.hku.hk/ajal/index.php/ajal/article/view/732 (accessed on 31 July 2021).

47. Pham, V.P.H. Teaching activities employed in the writing classrooms at the faculty of foreign languages at HCM OU. J. Sci. Ho Chi Minh City Open Univ. 2013, 3, 96-115.

48. Pham, V.P.H.; Usaha, S. Blog-based Peer Response for L2 Writing Revision. Comput. Assist. Lang. Learn. 2016, 29, 724-748. [CrossRef]

49. Zaman, M.M.; Azad, M.A.K. Feedback in EFL writing at tertiary level: Teachers' and learners' perceptions. ASA Univ. Rev. 2021, $6,139-156$.

50. Khader, F.R. Teachers' pedagogical beliefs and actual classroom practices in social studies instruction. Am. Int. J. Contemp. Res. 2012, 2, 73-92.

51. Dörnyei, Z. Questionnaires in Second Language Research: Construction, Administration, and Processing, 2nd ed.; Routledge: London, UK, 2010.

52. Ministry of Education and Training-MOET. The English Curriculum for the Secondary School; Education Publisher: Hanoi, Vietnam, 2006.

53. Nguyen, T.M. Textbook Evaluation: The Case of English Textbooks Currently in use at Vietnam's Upper-Secondary School; RELC SEAMEO: Singapore, 2007.

54. Thuy, N.H.H. Teaching EFL writing in Vietnam: Problems and solutions-a discussion from the outlook of applied linguistics. VNU J. Sci. Foreign Lang. 2009, 25, 61-66.

55. Luu, T.T. Teaching writing through genre-based approach. BELT J. 2001, 2, 121-136.

56. Wambui, S.E. Effects of Use of Instructional Materials on Learner Participation in Science Classroom in Preschool in Kiine Zone Kirinyaga Country Kenya. Master's Thesis, University of Nairobi, Nairobi, Kenya, 2013.

57. Peacock, M. The effect of authentic materials on the motivation of EFL learners. ELT J. Engl. Lang. Teach. J. 1997, 51, 144-156. [CrossRef]

58. Pham, V.P.H. The Effects of Collaborative Writing on Students' Writing Fluency: An Efficient Framework for Collaborative Writing. SAGE Open 2021, 11, 215824402199836. [CrossRef]

59. Pham, V.P.H.; Do, T.H. The Impacts of Task-based Instruction on Students' Grammatical Performances in Speaking and Writing Skills: A quasi-experimental study. Int. J. Instr. 2021, 14, 969-986. [CrossRef]

60. Pham, V.P.H.; Phan, T.H.; Nguyen, N.H.V.; Nguyen, H.L. The Effects of Task-Based Instruction on EFL Students' Writing Accuracy and Fluency. Turk. Online J. Qual. Inq. 2021, 12, 39-49. Available online: https://tojqi.net/index.php/journal/article/view/2456 (accessed on 31 July 2021).

61. Pham, V.P.H.; Do, T.P.T. High School Students' Common Errors in Writing Essays. Int. J. Engl. Linguist. 2019, 9, 309-319. [CrossRef]

62. Ho, P.V.P.; Duong, P.N.T. Common errors in writing journals of the English major students at Ho Chi Minh City Open University. Soc. Sci. 2015, 5, 3-12. 